\title{
Synthesis and Anti-inflammatory Activity of Novel Furochromenes
}

\author{
Ivaylo Jivkov Elenkov, ${ }^{\text {a }}$ Boška Hrvačić, ${ }^{a}$ Stribor Marković, ${ }^{b}$ Milan Mesić, ${ }^{a}$ Andreja Čempuh \\ Klonkay, ${ }^{\mathrm{c}}$ Lidija Lerman, ${ }^{\mathrm{c}}$ Anita Filipović Sučić, ${ }^{\mathrm{d}}$ Ines Vujasinović, ${ }^{\mathrm{a}}$ Berislav Bošnjak, \\ Karmen Brajša, ${ }^{\mathrm{a}}$ Dinko Žiher, ${ }^{\mathrm{a}}$ Nada Košutić Hulita, ${ }^{\mathrm{c}}$ and Ivica Malnar ${ }^{\mathrm{d}, *}$
}

\author{
GlaxoSmithKline Research Centre Zagreb Ltd., Prilaz baruna Filipovića 29, HR-10000 Zagreb, Croatia \\ ${ }^{a}$ Present address: Fidelta Ltd., Prilaz baruna Filipovića 29, HR-10000 Zagreb, Croatia \\ ${ }^{\mathrm{b}}$ Present address: Institute of Immunology, Inc., Rockefellerova 2, HR-10000 Zagreb, Croatia \\ ${ }^{c}$ Present address: PLIVA Croatia Ltd, Prilaz baruna Filipovića 25, HR-10000 Zagreb, Croatia \\ ${ }^{\mathrm{d}}$ Present address: Croatian Agency for Medicinal Products and Medical Devices, \\ Ksaverska cesta 4, HR-10000 Zagreb, Croatia \\ ${ }^{\mathrm{e}}$ Present address: Department of Dermatology, Division of Immunology, Allergy and Infectious Diseases, \\ Experimental Allergy, Medical University of Vienna, Lazarettgasse 19, A-1090 Vienna, Austria
}

RECEIVED FEBRUARY 2, 2013; REVISED MAY 2, 2013; ACCEPTED JUNE 13, 2013

\begin{abstract}
A series of variously substituted furochromenes, hemiacetals $\mathbf{2}$, acetals $\mathbf{3}$, and rearranged compounds 4, were synthesized from variously substituted 4-hydroxycoumarins and evaluated in several in vitro assays, inhibition of mast cell degranulation induced by the activation of Fce receptor type I or calcium ionophore and leukotriene $\mathrm{B}_{4}\left(\mathrm{LTB}_{4}\right)$ inhibition. The most active derivatives, $\mathbf{3 p}$ and $\mathbf{4 p}$ (8-iso-propyl substitution in coumarin ring) and 3r (5-methyl-8-chloro substitution), showed significant inhibition of mast cell degranulation (FcE-triggered) and $\mathrm{LTB}_{4}$, and exhibited significant local anti-inflammatory activity in PMA induced ear edema in CD1 mice, with potency equal (compounds $\mathbf{3 p}$ and $\mathbf{4 p}$ ) or better (compound 3r) in comparison with zileuton, a reference drug used. It might be a promising direction for developing novel drugs as potential agents for the treatment of allergies and other inflammatory diseases.(doi: $10.5562 / \mathrm{cca} 2240)$
\end{abstract}

Keywords: furochromenes; 4-hydroxycoumarins; mast cell degranulation; leukotriene $\mathrm{B}_{4}$; antiinflammatory activity; ear edema

\section{INTRODUCTION}

Coumarins represent an important class of oxygenated heterocycles. Since many of them, both naturally occurring and synthetic, possess diverse array of biological activities, they are also of potential pharmaceutical interest. In nature they act as plant growth regulation factors, UV-filters and protectors from sun radiation, or as insecticides, antivirals or antibacterial agents. ${ }^{1}$

4-Hydroxycoumarin was determined as a building unit of natural product dicoumarol, isolated from spoiled sweet clover and identified as a causative agent of haemorrhagic cattle deaths. ${ }^{2}$ The intensive investigations of many natural and synthetic coumarins resulted in discovery of warfarin and other 3-alkyl-4hydroxycoumarins as potent, clinically used anticoagulants, ${ }^{3-8}$ mainly used in postsurgical prevention of wound induced thrombus formation. Intensive investigation on the molecular level of action of these com- pounds showed that they prevent reduction of vitamin $\mathrm{K}$ epoxide to active vitamin $\mathrm{K}$ thus inhibiting the biosynthesis of protrombin and other clothing factors. ${ }^{9}$

Coumarins belonging to different chemical classes have been studied. ${ }^{10}$ There are evidences of the antiretroviral activity of coumarin derivatives and their ability to inhibit HIV integrase. ${ }^{11-14}$ Some 3-aryl and 3heteroaryl derivatives are inhibitors of macrophage migration inhibitory factor (MIF) ${ }^{15}$ while natural coumarin product cnidicin ${ }^{16}$ (Figure 1), isolated from the root extract of Angelica koreana (Umbelliferae), is an active component responsible for the inhibitory effect on the degranulation process of cultured mast cells. Cnidicin demonstrated a significant inhibition upon the release of $\beta$-hexosaminidase from the cultured RBL$2 \mathrm{H} 3$ cells in a dose dependent manner and the IC50 value was calculated as $25 \pm 2.1 \mu \mathrm{M}$, which is comparable to that of azelastine $(26 \pm 3.2 \mu \mathrm{M})$ an anti-allergic drug known to inhibit the degranulation of mast cells.

\footnotetext{
* Author to whom correspondence should be addressed. (E-mail: ivica.malnar@halmed.hr)
} 


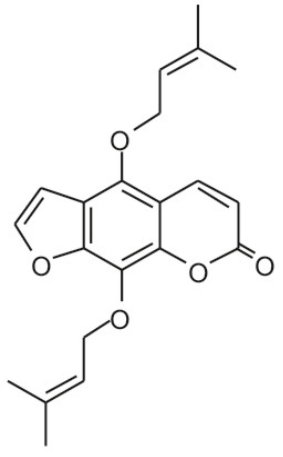

A

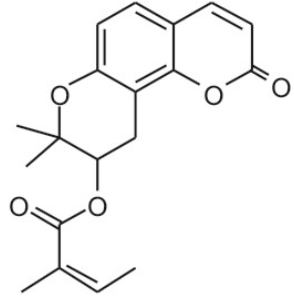

B
Figure 1. Cnidicin (A) and selinidin (B).

This result implied an anti-allergic action of cnidicin in vitro.

Another coumarin compound, selinidin (Figure $1),{ }^{17}$ isolated from the extract of A. keiskei is an antiallergic compound in screening employing rat basophilic leukemia RBL-2H3 cells. Selinidin had an inhibitory effect on degranulation of RBL-2H3 cells upon engagement of Fce receptor type I with IgE and antigen. Furthermore, it was shown that selinidin modulates Fce receptor type I mediated signaling although it does not prevent IgE-Fce receptor type I binding and cell surface Fce receptor type I expression. These results suggest that selinidin suppresses IgE-mediated mast cell activation by inhibiting signal transduction pathways through Fce receptor type I.

Also, it was documented that some synthetic aryl substituted 3-tetrazolylcoumarins, ${ }^{18,19}$ and 3-nitro-4hydroxycoumarins ${ }^{20,21}$ inhibit degranulation of mast cells thus preventing release of chemical mediators such as cysteinyl leukotrienes $\mathrm{C}_{4}, \mathrm{D}_{4}$ and $\mathrm{E}_{4}$ (originally described as slow-reacting substances of anaphylaxis, SRS-A) and histamine. In addition, a broad array of other therapeutic applications of natural and synthetic coumarins has been reported in the literature, especially concerning their anti-inflammatory / antioxidant properties, ${ }^{22-25}$ their application as neuroprotecting agents, ${ }^{26}$ as well as in pharmacotherapy of breast cancer. ${ }^{27}$

Furocoumarins are a class of natural and synthetic compounds used as photoreactive, antiviral, antiinflammatory agents as well as kinase inhibitors. ${ }^{28}$ Furo[4,3-c]coumarins are generally prepared by condensation of aryl substituted 4-hydroxycoumarins as dinucleophiles and vicinal dielectrophiles. ${ }^{26,29}$

In a quest for new anti-inflammatory / antiallergic therapeutics we screened our compound collection in mast cell degranulation assays and leukotriene $\mathrm{B}_{4}$ assay. Here, we wish to present the synthesis of several so far unreported classes of coumarin compounds, variously substituted furochromenes $\mathbf{2 - 4}$, as well as to report the results on evaluation of their biological activity.
Anti-inflammatory activity of prepared compounds was examined on the basis of in vitro tests, inhibition of mast cell (RBL-2H3 cell line of rat basophilic leukaemia) degranulation induced by the activation of Fce receptor type I. There is significant evidence that mast cells, basophils, and their released mediators are primary effectors of allergic inflammation. Mast cells may contribute to the pathophysiology of a wide variety of diseases including asthma, cardiomyopathy, schleroderma, arthritis, and fibrotic lung disorders. It is believed that many of the deleterious effects that mast cells mediate are due to a variety of proinflammatory molecules exocytosed with exposure to antigen and the subsequent crosslinking of cell-surface-bound immunoglobulin E (IgE), including histamine, serotonin, and the proteases tryptase, chymase, and carboxypeptidase. Furthermore, mast cell activation results in the release and increased production of cytokines including interleukins 4-6, tumor necrosis factor- alpha, prostaglandin $\mathrm{D}_{2}$, and leukotrienes $\mathrm{A}_{4}$ and $\mathrm{C}_{4}$. Clearly, modulation of mast cell activation and degranulation could significantly affect a number of disease states. ${ }^{30}$

The inhibition of degranulation may prevent the symptoms and arrest the inflammation progress, which has been proven by the clinical use of degranulation inhibitors (sodium chromoglycate, nedochromyl sodium and ketotifen). Cysteinyl leukotriene antagonists have also proven efficacy in asthma therapy. ${ }^{31}$ Therapeutically, the 5-lipoxygenase inhibitor, zileuton, is as effective as cysteinyl leukotriene antagonists, and its therapeutic effects are indistinguishable from those of the cysteinyl leukotriene antagonists. Number of $\mathrm{LTB}_{4}$ antagonists were reported as well. ${ }^{32}$

Discovery of new generation of compounds which would inhibit mast cell degranulation as well as prevent synthesis of leukotrienes potentially provides a therapeutic approach for treatment of allergies and other inflammatory diseases.

Anti-inflammatory potential of selected compounds was also evaluated in the in vivo antiinflammatory model of phorbol 12-myristate 13-acetate (PMA) induced ear oedema in CD1 mice. Mouse ear inflammation induced by different irritants, including PMA provides a range of skin inflammation models suitable for the evaluation of both topical and systemic anti-inflammatory agents. ${ }^{33}$

\section{EXPERIMENTAL SECTION}

\section{General methods}

Starting 4-hydroxycoumarins $\mathbf{1 a}, \mathbf{d}, \mathbf{f}-\mathbf{h}$ and $\mathbf{l}$ were commercially available. All other 4-hydroxycoumarins $\mathbf{1} \mathbf{b}-\mathbf{c}, \mathbf{e}, \mathbf{i}-\mathbf{k}, \mathbf{m}-\mathbf{r}$ were synthesised according to protocols described in literature ${ }^{34}$ and references cit- 
ied therein. NMR spectra were recorded at $24{ }^{\circ} \mathrm{C}$ on a Bruker Avance DPX 300 spectrometer. Chemical shifts are reported as $\delta$ (ppm) relative to TMS as internal standard, and $J$ is in $\mathrm{Hz}$. High performance liquid chromatography-mass spectrometry (HPLCMS) analysis were performed using a Waters XTerra RP18 analytical column (packing: $3.0 \times 100 \mathrm{~mm}$ ) on a Quattro micro ${ }^{\mathrm{TM}}$ (Micromass) mass spectrometer, using external calibration. Gradient was from $20 \%$ $\mathrm{MeCN} / 0.1 \%$ TFA in water to $80 \% \mathrm{MeCN} / 0.1 \%$

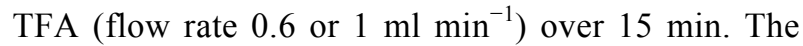
UV absorption was monitored at $310 \mathrm{~nm}$. Reported values are monoisotopic masses. For all synthesized compounds determined purities were $\geq 95 \%$ by HPLC-UV-MS.

\section{Synthesis}

General synthetic methodology for Furochromenes 2-4 General methodology to prepare hemiacetals 2 . Appropriate 4-hydroxycoumarin 1 (1 mmol) was mixed with a $40 \%$ aqueous solution of glyoxal $(2.5 \mathrm{mmol})$. Acetonitrile $(5-10 \mathrm{ml})$ was added thereto and the reaction mixture was refluxed for 2-6 hours. After cooling the product was filtered and washed with acetonitrile, affording hydroxy furochromen derivatives $\mathbf{2 a}-\mathbf{p}$ as pure compounds.

General methodology to prepare acetals 3. Into a solution of appropriate 4-hydroxycoumarin 1 (1 mmol) in $\mathrm{MeOH}(5 \mathrm{ml})$ was added aqueous dimethoxyacetaldehyde ( $60 \%$ solution, $8 \mathrm{mmol}$ ). Reaction mixture was stirred at reflux temperature for 5 hours. After cooling to room temperature, product was collected by filtration and washed with $\mathrm{MeOH}$, affording $\mathbf{3 a}-\mathbf{r}$ as pure compounds.

General methodology to prepare rearranged compounds 4. Appropriate metoxy furochromen derivative 3 $(0.3 \mathrm{mmol})$ was suspended in acetic acid $(5 \mathrm{ml})$. The reaction mixture was refluxed for 1-24 hours, whereat the starting material was dissolved, and then a precipitate was formed. After cooling to the room temperature the product was collected by filtration and washed with acetic acid and diethyl ether, affording furochromen derivatives $\mathbf{4}$ as pure compounds.

Synthetic procedure for enol ether $\mathbf{5}$. To a suspension of $2 \mathbf{a}(0.412 \mathrm{mmol})$ in $\mathrm{Me}_{2} \mathrm{CO}(10 \mathrm{ml})$ powdered anhydrous $\mathrm{K}_{2} \mathrm{CO}_{3}(2.89 \mathrm{mmol})$ was added, followed by $\mathrm{Me}_{2} \mathrm{SO}_{4}(2.12 \mathrm{mmol})$. Reaction mixture was heated to reflux and vigorously stirred for 24 hours, cooled to room temperature, followed by filtration. The filtrate was evaporated to dryness and the residue then triturated with ice-cold water for 10 minutes, filtered off and recrystallized from $\mathrm{MeOH}(140 \mathrm{mg} / 25 \mathrm{ml})$ to obtain product 5.

Synthetic procedure for acetylation of compound 3a. A suspension of $\mathbf{3 a}(1.05 \mathrm{mmol})$ in $\mathrm{Ac}_{2} \mathrm{O}(12 \mathrm{ml})$ was stirred at reflux for $1 \mathrm{~h}$. After cooling to room temperature, resulting precipitate was collected by filtration, washed with $\mathrm{CH}_{3} \mathrm{CN}$ to afford product $\mathbf{6}$, which was further recrystallized from $\mathrm{Ac}_{2} \mathrm{O}$.

2-hydroxy-3-(4-hydroxy-2-oxo-2H-chromene-3-yl)2,3-dihydro-4H-furo[3,2c]chromene-4-one (2a). (0.13 g, $74 \%$ ); white solid; ${ }^{1} \mathrm{H}-\mathrm{NMR}$ (300 MHz, DMSO-d 6 ) $\delta / \mathrm{ppm}: 4.84(\mathrm{~s}, 1 \mathrm{H}), 6.29(\mathrm{bs}, 1 \mathrm{H}), 7.28-7.58(\mathrm{~m}$, $4 \mathrm{H}), 7.63-7.80(\mathrm{~m}, 3 \mathrm{H}), 8.04(\mathrm{~d}, \mathrm{~J}=7.6 \mathrm{~Hz}, 1 \mathrm{H})$, 12.02 (bs, 1H); ${ }^{13} \mathrm{C}-\mathrm{NMR}\left(75.4 \mathrm{MHz}, \mathrm{DMSO}-\mathrm{d}_{6},\right) \delta /$ ppm: 43.8, 101.6, 101.9, 109.6, 111.9, 115.8, 116.3, $116.6,122.6,123.3,123.9,124.3,132.3,132.7,152$, 154.1, 158.4, 161.4, 161.9, 164.9; ES-MS m / z: 363.2 $[\mathrm{M}-\mathrm{H}]^{-}$.

3-(4-hydroxy-2-oxo-2H-benzo[g]chromene-3-yl)-2methoxy-2,3-dihydro-4H-benzo[g]furo[3,2-c]chromene4-one (3a). (0.15 g, $80 \%)$; white solid; ${ }^{1} \mathrm{H}-\mathrm{NMR}(300$ MHz, DMSO-d $\left.{ }_{6}\right) \delta /$ ppm: $3.69(\mathrm{~s}, 3 \mathrm{H}), 5.02(\mathrm{~d}, J=2$ $\mathrm{Hz}, 1 \mathrm{H}), 6.24(\mathrm{~d}, J=3.5 \mathrm{~Hz}, 1 \mathrm{H}), 7.54-7.71(\mathrm{~m}, 2 \mathrm{H})$, $7.90(\mathrm{~s}, 1 \mathrm{H}), 7.98(\mathrm{~s}, 1 \mathrm{H}), 7.99-8.10(\mathrm{~m}, 2 \mathrm{H}), 8.21(\mathrm{~d}, J$ $=7.9 \mathrm{~Hz}, 1 \mathrm{H}), 8.51(\mathrm{~s}, 1 \mathrm{H}), 8.67(\mathrm{~s}, 1 \mathrm{H}) ;{ }^{13} \mathrm{C}-\mathrm{NMR}$ (75.4 MHz, DMSO-d ${ }_{6}$ ) $\delta /$ ppm: 42.5, 56.6, 100.8, $102.1,111.9,114.6,115.8,116.3,116.6,122.6,123.5$, $124,124.4,132.5,132.9,152.1,154.1,158.2,161.4$, 162, 165; ES-MS m/z : $379.2[\mathrm{MH}]^{+}$.

2-(4-hydroxy-2-oxo-2H-chromene-3-yl)-4H-furo [3,2c]chromene-4-one (4a). (0.05 g, $45 \%)$; yellow solid; ${ }^{1} \mathrm{H}-\mathrm{NMR}\left(300 \mathrm{MHz}, \mathrm{DMSO}-\mathrm{d}_{6}\right) \delta / \mathrm{ppm}$ : $7.28(\mathrm{~s}, 1 \mathrm{H})$, 7.39-7.49 (m, 3H), 7.52-7.79 (m, 3H), 7.96 (dd, $J=7.8$ $\mathrm{Hz}, J=1.4 \mathrm{~Hz}, 1 \mathrm{H}), 8.09(\mathrm{dd}, J=8.2 \mathrm{~Hz}, J=1.7 \mathrm{~Hz}$, $1 \mathrm{H}) ;{ }^{13} \mathrm{C}-\mathrm{NMR}$ (75 MHz, DMSO-d 6 ) $\delta / \mathrm{ppm:} \mathrm{108.2,}$ $110,112,115.9,116.2,116.6,120.6,123.7,123.9$, $124.4,130.4,132.8,149.7,151.7,151.9,152.3,155.6$, 156.7, 159.6, 163.6; ES-MS m/z : 345 [M-H] .

1,1-bis(4-methoxy-2-oxo-2H-chromen-3-yl)-2-methoxyethene (5). (0.08 g, $48 \%)$; colorless crystals; ${ }^{1} \mathrm{H}-\mathrm{NMR}$ $\left(300 \mathrm{MHz}, \mathrm{CDCl}_{3}\right) \delta / \mathrm{ppm}: 3.85(\mathrm{~s}, 3 \mathrm{H}), 4.05(\mathrm{~s}, 3 \mathrm{H})$, 4.13 (s, 3H), 6.89 (s, 1H), 7.22-7.32 (m, 4H), 7.45-7.52 $(\mathrm{m}, 2 \mathrm{H}), 7.73(\mathrm{dd}, J=1.5,7.9 \mathrm{~Hz}, 1 \mathrm{H}), 7.83(\mathrm{dd}, J=$ $1.5,7.9 \mathrm{~Hz}, 1 \mathrm{H}) ;{ }^{13} \mathrm{C}-\mathrm{NMR}\left(75 \mathrm{MHz}, \mathrm{CDCl}_{3}\right) \delta / \mathrm{ppm}$ : 59.8, 60.9, 61, 101.8, 106.9, 113.5, 116.3, 116.5, 118.1, $118.2,123.6,123.7,123.8,124,131.3,152.2,152.3$, 154.3, 162.66, 162.71, 162.97, 163; ES-MS m/z: 407.24 $[\mathrm{M}-\mathrm{H}]^{-}$.

3-(4-acetoxy-2-oxo-2H-chromen-3-yl)-2,3-dihydro-2methoxy-4H-furo[3,2-c]chromen-4-one (6). (0.38 g, 86 $\%$ ); white solid; recrystallization from $\mathrm{Ac}_{2} \mathrm{O}$ afforded colorless crystals; ${ }^{1} \mathrm{H}-\mathrm{NMR}\left(300 \mathrm{MHz}, \mathrm{DMSO}-\mathrm{d}_{6}\right) \delta /$ ppm : 2.26 (2, 3H), 3.69 (s, 3H), 5.02 (d, $J=2 \mathrm{~Hz}, 1 \mathrm{H})$, $6.24(\mathrm{~d}, J=3.5 \mathrm{~Hz}, 1 \mathrm{H}), 7.61-7.75(\mathrm{~m}, 2 \mathrm{H}), 7.90(\mathrm{~s}$, 1H), 7.98 (s, 1H), 7.89-8.13 (m, 2H), $8.21(\mathrm{~d}, J=7.9$ $\mathrm{Hz}, 1 \mathrm{H}), 8.51$ (s, 1H), 8.67 (s, 1H); ES-MS m/z: 421.3 $[\mathrm{M}-\mathrm{H}]^{-}$. 
Table 1. Crystal data and structure refinement for compounds 5 and 6

\begin{tabular}{|c|c|c|}
\hline Compound & 5 & 6 \\
\hline Empirical formula & $\mathrm{C}_{23} \mathrm{H}_{18} \mathrm{O}_{7}$ & $\mathrm{C}_{23} \mathrm{H}_{16} \mathrm{O}_{8}$ \\
\hline Formula weight & 406.37 & 420.36 \\
\hline Temperature (K) & $100(2)$ & 100 \\
\hline Wavelength $(\AA)$ & 1.54178 & 1.54178 \\
\hline Crystal system & monoclinic & monoclinic \\
\hline Space group & $\mathrm{P} 2{ }_{1} / \mathrm{c}$ & $\mathrm{P} 2_{1} / \mathrm{n}$ \\
\hline \multirow[t]{5}{*}{ Unit cell dimensions } & $a=14.0614(5) \AA$ & $a=9.5110(3) \AA$ \\
\hline & $b=8.3013(4) \AA$ & $b=16.5891(6) \AA$ \\
\hline & $c=17.9313(5) \AA$ & $c=12.6032(6) \AA$ \\
\hline & $\alpha=\gamma=90^{\circ}$ & $\alpha=\gamma=90^{\circ}$ \\
\hline & $\beta=112.060(5)^{\circ}$ & $\beta=111.200(11)^{\circ}$ \\
\hline Volume $\left(\AA^{3}\right)$ & $1939.85(15)$ & $1853.9(2)$ \\
\hline Z & 4 & 4 \\
\hline Calculated density $\left(\mathrm{Mg} \mathrm{m}^{-3}\right)$ & 1.391 & 1.506 \\
\hline Absorption coefficient $\left(\mathrm{mm}^{-1}\right)$ & 0.868 & 0.115 \\
\hline $\mathrm{F}(000)$ & 848 & 872 \\
\hline Crystal size (mm) & $0.4 \times 0.2 \times 0.2$ & $0.3 \times 0.3 \times 0.2$ \\
\hline Limiting indices & $-16 \leq h \leq 16$ & $-11 \leq h \leq 11$ \\
\hline Limiting indices & $-9 \leq k \leq 9$ & $-19 \leq k \leq 19$ \\
\hline Limiting indices & $-21 \leq l \leq 20$ & $-14 \leq l \leq 14$ \\
\hline Reflections collected / unique & $5638 / 3284[R(\mathrm{int})=0.1009]$ & $5834 / 3098[R(\mathrm{int})=0.0474]$ \\
\hline Refinement method & Full-matrix least-squares on $F^{2}$ & Full-matrix least-squares on $F^{2}$ \\
\hline Data / restraints / parameters & $3284 / 0 / 271$ & $3098 / 0 / 281$ \\
\hline Goodness-of-fit on $F^{2}$ & 1.027 & 0.981 \\
\hline Final R1 / wR2 $[I>2 \sigma(I)]$ & $0.0685 / 0.1921$ & $0.0529 / 0.1325$ \\
\hline R1 / wR2 (all data) & $0.0818 / 0.2102$ & $0.0833 / 0.1517$ \\
\hline Largest diff. peak / hole (e $\AA^{-3}$ ) & $0.310 /-0.233$ & $0.459 /-0.503$ \\
\hline Extinction coefficient & - & $0.036(5)$ \\
\hline
\end{tabular}

\section{X-Ray Crystallography}

Crystal structures of compounds $\mathbf{5}$ and $\mathbf{6}$ were determined by the single crystal X-ray diffraction method. Data were collected at $100 \mathrm{~K}$ with a Kappa-CCD Nonoius diffractometer using graphite monochromated $\mathrm{CuK} \alpha$ radiation. Data reduction was carried out using DENZO and SCALEPACK ${ }^{35}$ software. The details of crystal data collection and refinement parameters for compounds $\mathbf{5}$ and $\mathbf{6}$ are listed in Table 1. Further details on crystal structure investigation are available free of charge on application to CCDC, 12 Union Road, Cambridge CB2 IEZ, UK, www.ccdc.ac.uk/conts/retrieving.html or deposit@ccdc.cam.ac.uk under following deposition numbers; CCDC 941948 for compound 5 and CCDC 941949 for compound $\mathbf{6}$.

The structure was solved by direct methods implement in SHELXS97 $7^{36}$ and refined by a full-matrix leastsquares method based on $F^{2}$ using SHELXL97. ${ }^{35}$ Hydrogen atoms were positioned geometrically at calculated positions and allowed to ride on their parent atoms.

\section{Computational Studies}

Geometry optimization of examined compounds was performed using the density functional theory (DFT) at B3LYP ${ }^{37,38}$ level with $6-31 \mathrm{G}(\mathrm{d}, \mathrm{p})$ basis set. Zero-point vibration energy (ZPVE) correction with scaling factor 
of $0.9608^{39}$ was applied. Computations and visualizations were performed using $\mathrm{Jaguar}^{40}$ and Maestro ${ }^{41}$ programs, respectively, from the Schrödinger Suite 2011.

\section{Inhibition of RBL-2H3 Mast Cell Degranulation}

RBL-2H3 cell line of rat basophilic leukaemia (from ATCC) was used for the investigation of inhibition of degranulation induced by the activation of Fce receptor type I or calcium ionophors. RBL-2H3 cell line was cultivated in DMEM medium (Invitrogen Corporation Cat. No. 31966-021) with $10 \%$ of phoetal calf serum (Invitrogen Corporation) at $37{ }^{\circ} \mathrm{C}, 5 \% \mathrm{CO}_{2}, 90 \%$ relative humidity. Cells were seeded in the same medium into 24-well plates, 50000 per well, and left to reach 80 $90 \%$ of confluence.

Dilutions of compounds were prepared in DMEM medium without phenol red (Invitrogen Corporation) in concentrations from $200 \mu \mathrm{M}$ to $1 \mu \mathrm{M}$. The medium was removed from the cells and the diluted of compounds were added to the wells with the exception of the positive and the negative control where pure DMEM medium was added. Subsequently,

1. for the IgE-induced degranulation by Fce receptor type $I$, a solution of SPE-1 (dinitrophenyl specific IgE) antibodies (Sigma) and dinitrophenylalbumin (Sigma), both in a final concentration of $0.5 \mu \mathrm{g} \mathrm{ml}^{-1}$,

2. for $\mathrm{Ca}^{2+}$-induced degranulation by means of a calcium ionophore, the solution A23187 (Calbiochem) in a final concentration of $250 \mathrm{ng}$ $\mathrm{ml}^{-1}$, were added to the wells.

In the case of the negative control wells, pure DMEM medium was added. The cells were incubated for one hour at $37{ }^{\circ} \mathrm{C}, 5 \% \mathrm{CO}_{2}$, and $90 \%$ relative humidity. Each dilution as well as the positive and the negative controls were performed in triplicate.

The supernatant $(50 \mu \mathrm{l})$ was transferred in duplicate to a 96-well plate. Thereto $100 \mu \mathrm{l}$ of $50 \mathrm{mM}$ sodium citrate buffer with $1 \mathrm{mg} \mathrm{ml}^{-1}$ para-nitrophenyl-N-acetyl- $\beta$ D-glucosaminide (Calbiochem) were added and it was incubated for 1 hour at $37^{\circ} \mathrm{C}$. The reaction was stopped with $100 \mu \mathrm{l}$ of a saturated sodium carbonate solution. The absorbance was measured at $405 \mathrm{~nm}$. The percentage of inhibition was expressed by the formula:

$\%$ inhibition $=\left(1-\left(\mathrm{OD}_{405}\right.\right.$ sample $-\mathrm{OD}_{405}$ negative control $) /\left(\mathrm{OD}_{405}\right.$ positive control - $\mathrm{OD}_{405}$ negative control)) $\times 100$.

Ketotifen, used as a standard, significantly inhibits degranulation in concentrations from $200-50 \mu \mathrm{M}$.

\section{Leukotriene $\mathrm{B}_{4}\left(\mathrm{LTB}_{4}\right)$ Inhibition Assay}

Compounds were assayed for their ability to inhibit the production of leukotriene $\mathrm{B}_{4}$ in $\mathrm{A} 23187$ stimulated RBL-2H3 cells. RBL-2H3 cell line (ATCC 2256) is grown in DMEM medium (Invitrogen) supplemented with $10 \%$ FBS (Invitrogen) in the atmosphere of $5 \%$ $\mathrm{CO}_{2}, 90 \%$ humidity, $37{ }^{\circ} \mathrm{C}$. Cells are trypsinazed, washed with fresh DMEM medium and adjusted to $1 \times$ $10^{5}$ cells $/ \mathrm{ml} .500 \mu \mathrm{l} /$ well of cell suspension is transferred into 24 well plate (Falcon) and grown overnight in culturing condition described herein. $10 \mathrm{mM}$ solutions of tested compounds are prepared in DMSO (Sig$\mathrm{ma}$ ), and dissolved in working concentrations in DMEM medium without phenol red (Invitrogen). Dilutions of tested compounds are placed on cells, whereas for positive and negative controls only DMEM medium without phenol red are used and left in culturing conditions for 30 minutes. A23187 (Sigma) was added into all wells except negative controls in the final concentration of $250 \mathrm{nM}$ and left for 45 minutes in culturing conditions. $10 \mu \mathrm{l}$ of cellular supernatant was used to determine leukotriene $\mathrm{B}_{4}$ levels using ELISA (R\&D systems). Total concentrations of $\mathrm{LTB}_{4}$ are calculated in samples and total inhibition was calculated using the formula:

$\%$ inhibition $=\left(1-\mathrm{LTB}_{4}\right.$ sample concentration / $\mathrm{LTB}_{4}$ positive control concentration $) \times 100$.

\section{Phorbol 12-myristate 13-acetate (PMA) Induced Ear Oedema in CD1 Mice}

Male CD1 mice (Iffa Credo, France) weighing $\approx 35-40$ g were randomly grouped $(n=8$ in vehicle treated test group, dexamethasone treated control group as well as in groups treated with compounds to be assayed). Test compounds, dexamethasone as well as vehicle (Transphase Delivery System, containing benzyl alcohol $10 \%$, acetone $40 \%$ and isopropanol $50 \%$ ) (all from Kemika, Croatia), were administered topically to the internal surface of the left ear thirty minutes prior to administration of phorbol 12-myristate 13-acetate (PMA) (Alexis biochemicals, USA). Test compounds were administered at a single dose of 250 or $100 \mu \mathrm{g} / 15 \mu \mathrm{l} /$ ear and dexamethasone at a single dose of $50 \mu \mathrm{g} / 15 \mu \mathrm{l} /$ ear. Thirty minutes later, $0.01 \%$ PMA solution in acetone was applied topically to the same area of each animal in a volume of $12 \mu 1 /$ ear. During the treatment and challenge, animals were anaesthetized by using inhalation anaesthesia. Six hours after the challenge, animals were euthanized by asphyxiation in $100 \% \mathrm{CO}_{2}$ atmosphere. For assessing the auricular oedema, $8 \mathrm{~mm}$ discs were cut out of left and right auricular pinna and weighed. The degree of oedema was calculated by subtracting the weight of $8 \mathrm{~mm}$ disc of the untreated ear from that of the treated contralateral ear.

The compound at appropriate dose is considered active if the supression of ear oedema in compound treated group is statistically significantly different in comparison to positive control group, as calculated by the non-parametric ANOVA statistical method (statistical analysis was done using the program GraphPad 
<smiles>[R]c1cc2oc(=O)cc(O)c2c([R])c1[R]</smiles>

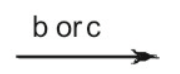<smiles>[3H][13CH3]</smiles><smiles>[R]c1c([R])c([R])c2c([R])c(C(c3c(O)c4c([R])c([R])c([R])c([R])c4oc3=O)C(O)O)c(=O)oc2c1[R]</smiles>

2<smiles></smiles><smiles>[R]c1c([R])c([R])c2c(O)c(-c3cc4c(=O)oc5c([R])c([R])c([R])c([R])c5c4o3)c(=O)oc2c1[R]</smiles>

4

Scheme 1. Synthesis of furochromen compounds 2-4. Reagents and conditions: a) glyoxal, MeCN, reflux; b) glyoxal, $\mathrm{MeOH}$, reflux; c) dimethoxyacetaldehyde, $\mathrm{MeOH}$, reflux; d) $\mathrm{AcOH}$ or TFA, reflux.

\section{InStat v.3.06.}

Statement. All procedures on animals were performed in accordance with (a) the EEC Council Directive 86 / 609 of 24th November 1986 on the approximation of laws, regulations and administrative provisions of the Member States regarding the protection of animals used for experimental and other scientific purposes; and (b) Statute of Republic Croatia, Animal Welfare Law, NN 135 of 13th December 2006.

\section{RESULTS AND DISCUSSION}

\section{Chemistry}

The compounds under study were prepared by condensation reaction of variously substituted hydroxycoumarins with glyoxal or dimethoxyacetaldehyde as dielec- trophiles via tandem Knöevenagel / Michael addition reaction, followed by annulation and dihydrofuran ring formation (Scheme 1). When reaction was performed in nonnucleophilic solvent, such as acetonitrile, hemiacetals $\mathbf{2}$ were isolated as final products while acetals $\mathbf{3}$ were isolated after condensation in alcoholic solvent, e.g. methanol (as exemplified in this paper) or ethanol (not shown). Treatment of either $\mathbf{2}$ or $\mathbf{3}$ with dehydrating agents such as acetic acid or trifluoroacetic acid (TFA) resulted in the formation of new class of 2-substituted furo[3,2-c]chromens 4 . In this case elimination of C-2 substituent is accompanied by rearrangement and migration of the second coumarin moiety to $\mathrm{C}-2$ position via neighbouring participation of $3^{\prime}-4$ ' double bond and formation of spiro[chroman-cycopropane]dione intermediate. 2-Methyl-4H-furo[3,2-c]chromen-4-one is already reported as a product of such rearrangement. ${ }^{42}$

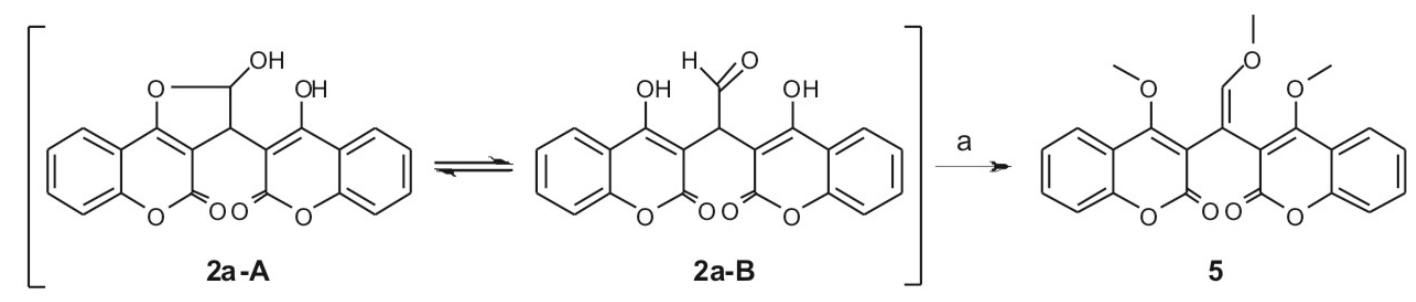

a) $\mathrm{Me}_{2} \mathrm{SO}_{4}, \mathrm{~K}_{2} \mathrm{CO}_{3}, \mathrm{Me}_{2} \mathrm{CO}, \Delta$

Scheme 2. Cyclic (2a-A) and open chain (2a-B) isomeric forms of $\mathbf{2}$ and product of methylation (5). 
Keto-enol tautomerism is the most common structural isomerism in 4-hydroxycoumarins. Due to dynamic equilibrium tautomers are rapidly interconvertible from one isomeric form to another and tautomer determination is quite challenging. ${ }^{43}$ Other structural isomers are possible as well. In our studies we noticed that in compounds 2 ring-chain tautomerism ${ }^{44}$ also exists (Scheme 2). Which of the isomeric form prevails in the mixture, cyclic (hemiacetal) or open chain (aldehyde), depends on the nature and number of the aromatic substituents, whether the compound is in a free acid form or as a salt. Type of the salt, type of the solvent in which the compound is dissolved, as well as the $\mathrm{pH}$ value of the solution also have an effect on the tautomer ratio.

For the purpose of structure elucidation NMR spectra of investigated compounds were run in DMSO$d_{6}$. The cyclic form (i.e. 2a-A) prevails in such solutions with anomeric proton (H-2) at ppm 6.2 and H-3 at 4.8. Existence of open chain form was confirmed by standard methylation reaction with dimethyl sulphate in the presence of potassium carbonate. Enol ether 5 was isolated as the only reaction product (Scheme 2). The molecular and crystal structures of $\mathbf{5}$ were determined by single-crystal X-ray diffraction (Figure 2, Table 1).

Both series of compounds $\mathbf{2}$ and $\mathbf{3}$ contain two stereocenters and therefore 4 possible stereoisomers

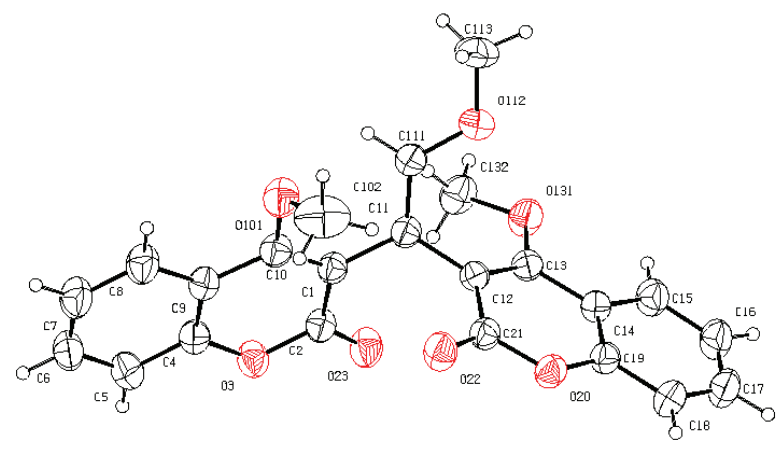

Figure 2. The molecular structure of compound 5.

could be expected. However, the pair of enantiomers with trans- configuration around $\mathrm{C} 2-\mathrm{C} 3$ bond in $\mathbf{3}$ is calculated to be more favorable (Figure 3), which was determined experimentally as well.

Acetylation of $\mathbf{3 a}$ afforded compound $\mathbf{6}$ (Scheme 3 ), whose molecular and crystal structures (Figure 4) were determined by single-crystal X-ray diffraction (Table 1) and product was shown to be a racemic mixture with trans configuration around $\mathrm{C} 2-\mathrm{C} 3$ bond, suggesting (trans)-diastereoselectivity in the formation of acetal 3a.

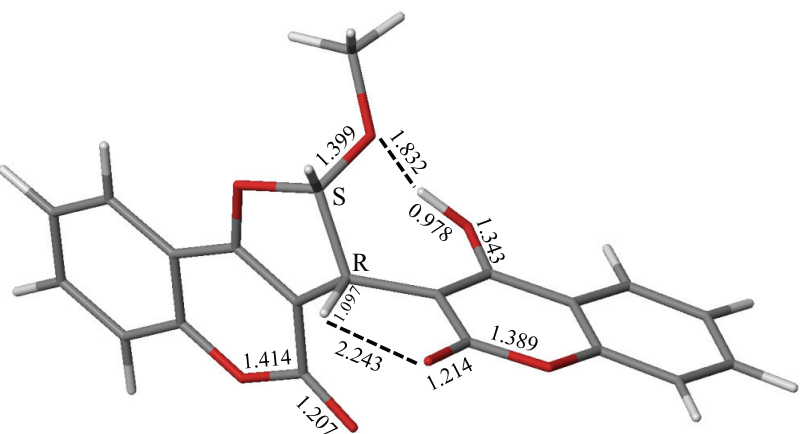

$\operatorname{cis}-(R, S)-\mathbf{3 a}[(S, R)-\mathbf{3}]$

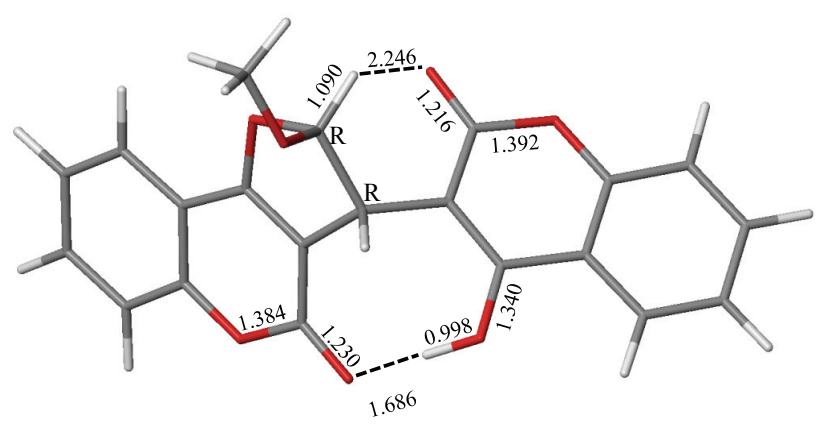

trans- $(R, R)-\mathbf{3 a}[(S, S)-\mathbf{3}]$

$\Delta E_{0}($ cis-trans $)=6.1 \mathrm{kcal} \mathrm{mol}^{-1}$

Figure 3. Trans-3a recognized as favored product over cis-3a.<smiles></smiles>

3a<smiles>COC1Oc2c(c(=O)oc3ccccc23)C1c1c(OC(C)=O)c2ccccc2oc1=O</smiles>

6

Scheme 3. Acetylation of 3a affords compound 6. 


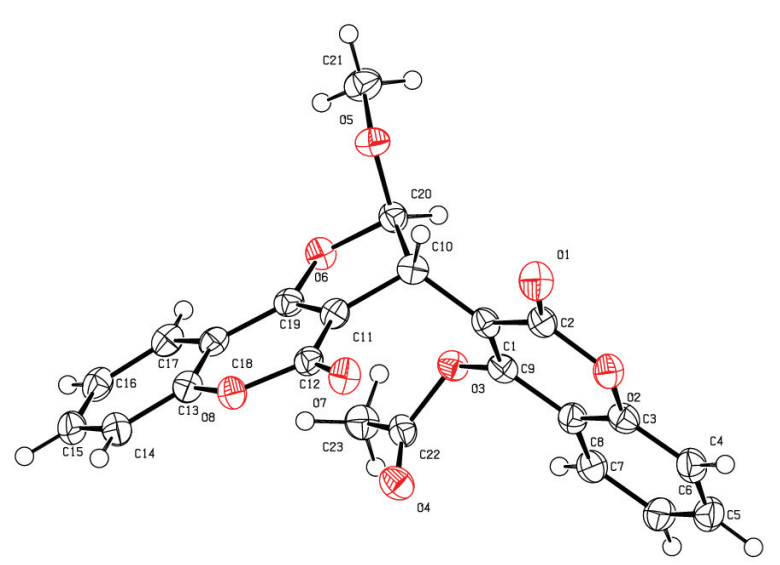

Figure 4. The molecular structure of compound 6.

\section{Pharmacology}

The synthesized compounds were evaluated for their anti-inflammatory activity in the in vitro RBL-2H3 rat mast cells degranulation which was Fce receptor or $\mathrm{Ca}^{2+}$-triggered, and by inhibition of leukotriene $\mathrm{B}_{4}$ $\left(\mathrm{LTB}_{4}\right)$, at inhibitor concentration of $10 \mu \mathrm{M}{ }^{45}$ For most of them Fce receptor triggered degranulation were repeated with inhibitor concentration of $30 \mu \mathrm{M}$ indicating dose-response behavior of analyzed compounds. Results are summarized in Tables $2-4$. Compounds that significantly inhibited (i.e. $50 \%$ or higher) degranulation of mast cells or $\mathrm{LTB}_{4}$ are considered to be fully "active" and to possess anti-inflammatory activity.

The central role of the mast cell in the initiation of allergic responses makes it an ideal target for antiallergic drug therapy. Mast cells are the primary initiating cells of immediate hypersensitivity reactions so their degranualtion is indicated as invoked in immediate or delayed type hypersensitivity reaction, allergy, anaphylaxis, inflammation, asthma and urticaria. ${ }^{46}$ Immunological activation of mast cells results not only in degranulation but also in the liberation of arachidonic acid from phospholipids in the cell membrane. Their further

Table 2. Inhibition (\%) of $\mathrm{Fc} \varepsilon$ receptor triggered $(\mathrm{Fc} \varepsilon)$ and $\mathrm{Ca}^{2+}$-induced $\left(\mathrm{Ca}^{2+}\right)$ degranulations as well as leukotriene $\mathrm{B}_{4}\left(\mathrm{LTB}_{4}\right)$ production in RBL-2H3 rat mast cells for hemiacetales $\mathbf{2 a - 2 p}$ at an inhibitor concentration of $10 \mu \mathrm{M}$

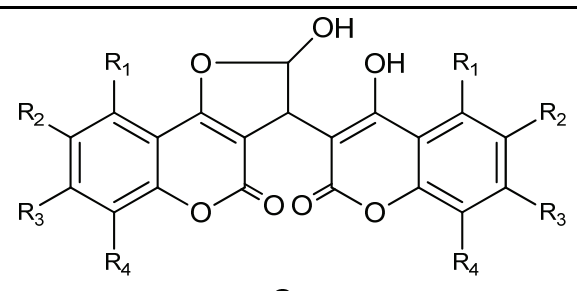

2

\begin{tabular}{|c|c|c|c|c|c|c|c|c|}
\hline \multirow[b]{2}{*}{ Cpd } & \multirow[b]{2}{*}{$\mathrm{R}_{1}$} & \multirow[b]{2}{*}{$\mathrm{R}_{2}$} & \multirow[b]{2}{*}{$\mathrm{R}_{3}$} & \multirow[b]{2}{*}{$\mathrm{R}_{4}$} & \multicolumn{2}{|l|}{ Fce } & \multirow{2}{*}{$\frac{\mathrm{Ca}^{2+}}{10 \mu \mathrm{M}}$} & \multirow{2}{*}{$\frac{\mathrm{LTB}_{4}}{10 \mu \mathrm{M}}$} \\
\hline & & & & & $10 \mu \mathrm{M}$ & $30 \mu \mathrm{M}^{(\mathrm{a})}$ & & \\
\hline $2 a$ & $\mathrm{H}$ & $\mathrm{H}$ & $\mathrm{H}$ & $\mathrm{H}$ & 0 & $\mathrm{ND}^{(\mathrm{b})}$ & 0 & 0 \\
\hline $2 b$ & $\mathrm{H}$ & $\mathrm{OH}$ & $\mathrm{H}$ & $\mathrm{H}$ & 0 & $\mathrm{ND}^{(\mathrm{b})}$ & 0 & 0 \\
\hline $2 c$ & $\mathrm{H}$ & $\mathrm{OMe}$ & $\mathrm{H}$ & $\mathrm{H}$ & 0 & $\mathrm{ND}^{(\mathrm{b})}$ & 2 & 23 \\
\hline $2 d$ & $\mathrm{H}$ & $\mathrm{Cl}$ & $\mathrm{H}$ & $\mathrm{H}$ & 64 & 83 & 0 & 0 \\
\hline $2 e$ & $\mathrm{H}$ & $\mathrm{H}$ & $\mathrm{Cl}$ & $\mathrm{H}$ & 75 & 87 & 13 & 13 \\
\hline $2 f$ & $\mathrm{H}$ & $\mathrm{Me}$ & $\mathrm{H}$ & $\mathrm{H}$ & 0 & $\mathrm{ND}^{(\mathrm{b})}$ & 0 & 18 \\
\hline $2 \mathrm{~g}$ & $\mathrm{H}$ & $\mathrm{H}$ & $\mathrm{Me}$ & $\mathrm{H}$ & 15 & 35 & 0 & 34 \\
\hline $2 \mathrm{~h}$ & $\mathrm{H}$ & $\mathrm{Me}$ & $\mathrm{Me}$ & $\mathrm{H}$ & 50 & 95 & 23 & 100 \\
\hline $2 \mathrm{i}$ & $\mathrm{Me}$ & $\mathrm{H}$ & $\mathrm{H}$ & $\mathrm{Me}$ & 90 & 95 & 22 & 100 \\
\hline $2 j$ & $\mathrm{Me}$ & $\mathrm{H}$ & $\mathrm{Me}$ & $\mathrm{H}$ & 67 & 92 & 50 & 100 \\
\hline $2 k$ & $\mathrm{H}$ & $\mathrm{Me}$ & $\mathrm{H}$ & $\mathrm{Me}$ & 50 & 95 & 12 & 39 \\
\hline 21 & $\mathrm{H}$ & $\mathrm{Cl}$ & $\mathrm{Me}$ & $\mathrm{H}$ & 50 & 90 & 18 & 33 \\
\hline $2 m$ & $\mathrm{H}$ & Et & $\mathrm{H}$ & $\mathrm{H}$ & 30 & 90 & 11 & 100 \\
\hline $2 n$ & $\mathrm{H}$ & $\mathrm{H}$ & $\mathrm{H}$ & Et & 64 & 93 & 10 & 68 \\
\hline 20 & $\mathrm{H}$ & $i-\operatorname{Pr}$ & $\mathrm{H}$ & $\mathrm{H}$ & 70 & 80 & 0 & 100 \\
\hline $2 p$ & $\mathrm{H}$ & $\mathrm{H}$ & $\mathrm{H}$ & $i$-Pr & 80 & 91 & 5 & 100 \\
\hline Dicoumarol & & & & & 45 & 45 & 13 & 0 \\
\hline Ketotifen & & & & & 0 & 30 & $\mathrm{ND}^{(\mathrm{b})}$ & $\mathrm{ND}^{(\mathrm{b})}$ \\
\hline Zileuton & & & & & 22 & 28 & 0 & 100 \\
\hline
\end{tabular}

${ }^{\text {(a) }}$ Inhibitor concentration of $30 \mu \mathrm{M} .{ }^{(b)} \mathrm{ND}=$ not determined. 
Table 3. Inhibition (\%) of $\mathrm{Fc} \varepsilon$ receptor triggered $(\mathrm{Fc} \varepsilon)$ and $\mathrm{Ca}^{2+}$-induced $\left(\mathrm{Ca}^{2+}\right)$ degranulations as well as leukotriene $\mathrm{B}_{4}\left(\mathrm{LTB}_{4}\right)$ production in RBL-2H3 rat mast cells for acetals $\mathbf{3 a}-\mathbf{3 r}$ at an inhibitor concentration of $10 \mu \mathrm{M}$

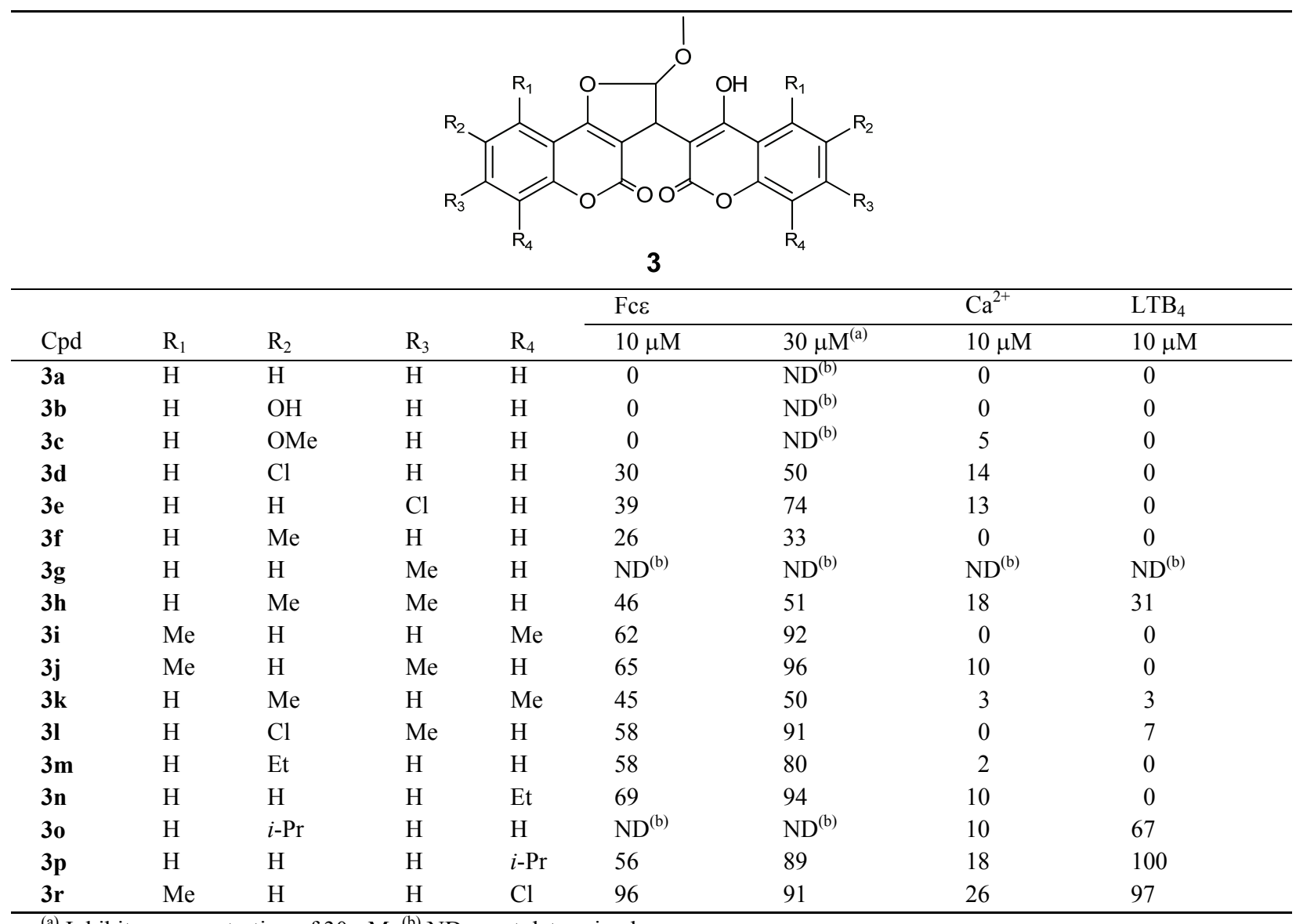

${ }^{\text {(a) }}$ Inhibitor concentration of $30 \mu \mathrm{M} .{ }^{(b)} \mathrm{ND}=$ not determined.

metabolism may proceed along either of two independent pathways, the cyclooxygenase pathway toward prostaglandins and the lypoxygenase pathway which has the capacity to generate a wide variety of leukotriene products. Leukotrienes are important mediators in host defense mechanisms and in inflammatory disease states due, for example, to their effects on cell migration, muscle contraction, vascular permeability, and the release of lysozomal enzymes. ${ }^{47}$

It was observed that majority of studied compounds inhibit mast cells degranulation triggered by Fe $\varepsilon$ receptor, and only few of them inhibit degranulation triggered by $\mathrm{Ca}^{2+}$. Significant inhibition of mast cell degranulation induced by the activation of $F c \varepsilon$ receptor type I showed certain derivatives with alkyl and halogen substituents as well as combinations of those substituents, whereas unsubstituted compounds and those with hydroxy and methoxy substituents gave the poorest inhibitions. Further, hemiacetals 2 proved to be the most active ones, regarding the in vitro activity, but during evaluation were proven to be chemically unstable and because of that were not fully investigated. ${ }^{48}$ Acetals $\mathbf{3}$ and rearranged compounds $\mathbf{4}$ are equally potent inhibitors of mast cell (RBL-2H3) degranulation (Fce-triggered).

The most potent inhibitors of Fce-triggered mast cell degranulation bear liphophilic substituent at $R_{4}$ position. The potency of derivatives at $\mathrm{R}_{4}$ follows the tendency of $\mathbf{2 - 4 p}$ (isopropyl) $>\mathbf{2 - 4 n}$ (ethyl). Methyl at $\mathrm{R}_{4}$ is well tolerated in combination with additional methyl group at $R_{1}$ position as in $\mathbf{2 - 4 i}$. Introduction of lipophilic substituent at $R_{3}$ position, like chlorine in $\mathbf{2}$ 4e and methyl in $\mathbf{2 g}$ and $\mathbf{4 g}$ has positive effect on Fce-triggered inhibition of mast cell degranulation, especially in combination with additional substitution with methyl at $R_{1}$ as in compounds $\mathbf{2}-\mathbf{4 j}$. However, $R_{1} /$ $\mathrm{R}_{3}$ combination in $\mathbf{2} \mathbf{- 4} \mathbf{j}$ was somewhat less potent than $\mathrm{R}_{1} / \mathrm{R}_{4}$ in $\mathbf{2 - 4 i}$. Finally, $\mathrm{R}_{2}$ position tolerates only lipophilic substituents, and the inhibitory potency of derivatives followed the tendency of 2-4o (isopropyl) $>\mathbf{2 - 4 d}$ (chlorine) $>\mathbf{2 - 4 m}$ (ethyl). Less lipophilic or polar groups like methyl (2-4f), hydroxy (2-4b), methoxy (2- 
Table 4. Inhibition (\%) of $\mathrm{Fc} \varepsilon$ receptor triggered $(\mathrm{Fc} \varepsilon)$ and $\mathrm{Ca}^{2+}$-induced $\left(\mathrm{Ca}^{2+}\right)$ degranulations as well as leukotriene $\mathrm{B}_{4}\left(\mathrm{LTB}_{4}\right)$ production in RBL-2H3 rat mast cells for 2-substituted furo[3,2]coumarins $4 \mathbf{a}-\mathbf{4 p}$ at an inhibitor concentration of $10 \mu \mathrm{M}$<smiles>[R8]c1c([R])c([R])c2c(O)c(-c3cc4c(=O)oc5c([R])c([R])c([R])c([R])c5c4o3)c(=O)oc2c1[R8]</smiles>

\begin{tabular}{|c|c|c|c|c|c|c|c|c|}
\hline \multirow[b]{2}{*}{ Cpd } & \multirow[b]{2}{*}{$\mathrm{R}_{1}$} & \multirow[b]{2}{*}{$\mathrm{R}_{2}$} & \multirow[b]{2}{*}{$\mathrm{R}_{3}$} & \multirow[b]{2}{*}{$\mathrm{R}_{4}$} & \multicolumn{2}{|l|}{$\mathrm{Fc} \varepsilon$} & \multirow{2}{*}{$\begin{array}{l}\mathrm{Ca}^{2+} \\
10 \mu \mathrm{M}\end{array}$} & \multirow{2}{*}{$\begin{array}{l}\text { LTB }_{4} \\
10 \mu \mathrm{M}\end{array}$} \\
\hline & & & & & $10 \mu \mathrm{M}$ & $30 \mu \mathrm{M}^{(\mathrm{a})}$ & & \\
\hline $4 a$ & $\mathrm{H}$ & $\mathrm{H}$ & $\mathrm{H}$ & $\mathrm{H}$ & 0 & $\mathrm{ND}^{(b)}$ & 0 & 0 \\
\hline $4 b$ & $\mathrm{H}$ & $\mathrm{OH}$ & $\mathrm{H}$ & $\mathrm{H}$ & 0 & $\mathrm{ND}^{(\mathrm{b})}$ & 15 & 0 \\
\hline $4 c$ & $\mathrm{H}$ & $\mathrm{OMe}$ & $\mathrm{H}$ & $\mathrm{H}$ & 0 & $\mathrm{ND}^{(\mathrm{b})}$ & 0 & 0 \\
\hline $4 d$ & $\mathrm{H}$ & $\mathrm{Cl}$ & $\mathrm{H}$ & $\mathrm{H}$ & 0 & $\mathrm{ND}^{(\mathrm{b})}$ & 2 & 24 \\
\hline $4 e$ & $\mathrm{H}$ & $\mathrm{H}$ & $\mathrm{Cl}$ & $\mathrm{H}$ & 78 & 87 & 18 & 32 \\
\hline $4 \mathrm{f}$ & $\mathrm{H}$ & $\mathrm{Me}$ & $\mathrm{H}$ & $\mathrm{H}$ & 0 & $\mathrm{ND}^{(\mathrm{b})}$ & 6 & 0 \\
\hline $4 \mathrm{~g}$ & $\mathrm{H}$ & $\mathrm{H}$ & $\mathrm{Me}$ & $\mathrm{H}$ & 40 & 40 & 19 & 40 \\
\hline $4 h$ & $\mathrm{H}$ & $\mathrm{Me}$ & $\mathrm{Me}$ & $\mathrm{H}$ & 32 & $\mathrm{ND}^{(\mathrm{b})}$ & 0 & 0 \\
\hline $4 i$ & $\mathrm{Me}$ & $\mathrm{H}$ & $\mathrm{H}$ & $\mathrm{Me}$ & 55 & 78 & 6 & 41 \\
\hline $4 j$ & $\mathrm{Me}$ & $\mathrm{H}$ & $\mathrm{Me}$ & $\mathrm{H}$ & 35 & 65 & 0 & 29 \\
\hline $4 k$ & $\mathrm{H}$ & $\mathrm{Me}$ & $\mathrm{H}$ & $\mathrm{Me}$ & 26 & 30 & 24 & 6 \\
\hline 41 & $\mathrm{H}$ & $\mathrm{Cl}$ & $\mathrm{Me}$ & $\mathrm{H}$ & 68 & 80 & 15 & 31 \\
\hline $4 m$ & $\mathrm{H}$ & Et & $\mathrm{H}$ & $\mathrm{H}$ & $\mathrm{ND}^{(\mathrm{b})}$ & $\mathrm{ND}^{(\mathrm{b})}$ & 1 & 46 \\
\hline $4 n$ & $\mathrm{H}$ & $\mathrm{H}$ & $\mathrm{H}$ & Et & 68 & 71 & 59 & 32 \\
\hline 40 & $\mathrm{H}$ & $i-\operatorname{Pr}$ & $\mathrm{H}$ & $\mathrm{H}$ & 59 & 64 & 14 & 100 \\
\hline $4 p$ & $\mathrm{H}$ & $\mathrm{H}$ & $\mathrm{H}$ & $i$-Pr & 79 & 90 & 37 & 97 \\
\hline
\end{tabular}

${ }^{\text {(a) }}$ Inhibitor concentration of $30 \mu \mathrm{M} .{ }^{(b)} \mathrm{ND}=$ not determined.

4c), were not tolerated and led to almost complete loss of activity. Introduction of additional methyl group at $\mathrm{R}_{3}$ position increase activity, and generally it was determined that disubstituted $\mathrm{R}_{2} / \mathrm{R}_{3}(\mathbf{2}-\mathbf{4 h}$ and $\mathbf{2 - 4})$ derivatives were more potent that monosubstituted $R_{2}$ analogues (2-4f and $\mathbf{2 - 4 d}$, respectively). On the other hand, influence of substitutions on $\mathrm{LTB}_{4}$ inhibition among three classes is not equivocal. Mostly, substitutions with positive effect on Fce-triggered inhibition of mast cell degranulation also produce significant $\mathrm{LTB}_{4}$ inhibition. This trend correlates in series 2 and $\mathbf{4}$, but regarding series 3 , most of the substitutions at $\mathrm{R}_{1}, \mathrm{R}_{2}$ and $\mathrm{R}_{3}$ led to complete loss in $\mathrm{LTB}_{4}$ inhibition. Exceptions are most lipophilic substituents like isopropyl at $\mathrm{R}_{2}$ in 30 and at $R_{4}$ in 3p. Also combination of methyl at $R_{1}$ and chlorine at $\mathrm{R}_{4}$ in series $\mathbf{3}$, led to very potent compound 3r.

The most promising compounds were then selected for further evaluation in the in vivo antiinflammatory model of phorbol 12-myristate 13-acetate (PMA) induced ear oedema in CD1 mice (Table 5).
PMA induction of acute skin inflammation was conducted according to Napoletano et al. ${ }^{49}$ with some modifications. PMA is tumor-promoting agent, and protein kinase $\mathrm{C}$ activator widely used to induce cutaneous inflammation in experimental animal models.

Table 5. In vivo anti-inflammatory activity of selected compounds in the model of phorbol 12-myristate 13-acetate (PMA) induced ear oedema in CD1 mice

\begin{tabular}{lcc}
\hline Cpd & $\mu \mathrm{g} / \mathrm{ear}$ & $\begin{array}{c}\text { Ear oedema } \\
\text { \% inhibition* }\end{array}$ \\
\hline $\mathbf{3 p}$ & 250 & 71 \\
$\mathbf{3 p}$ & 100 & 39 \\
$\mathbf{3 r}$ & 100 & 68 \\
$\mathbf{4 p}$ & 100 & 33 \\
Zileuton & 100 & 38 \\
Dexamethasone & 50 & 89 \\
\hline
\end{tabular}

$* P<0.05$, Non-parametric ANOVA for all compounds 
Epicutaneous application of PMA results in vascular leakage, leukocyte infiltration, epidermal hyperplasia, activation of protein kinase $\mathrm{C}$ and increased release of arachidonic acid (AA) and its metabolites. ${ }^{50}$ The initiation of inflammatory responses by metabolites of AA and suppression of acute inflammatory responses by inhibitors of cyclooxygenase (COX) and lypoxygenase (LOX) establish an important role for metabolites of AA in acute inflammation induced by AA and PMA. ${ }^{51}$

Compounds 3r, 3p and $\mathbf{4 p}$ showed statistically significant suppression of ear eodema in comparison to positive control group, with comparable or even better activity to 5-LO and $\mathrm{LTB}_{4}$ inhibitor zileuton.

These findings attracted us to extend our research to this class of compounds in the quest for antiinflammatory - antiallergic medication.

\section{CONCLUSION}

Several new series of coumarin compounds, hemiacetals $\mathbf{2}$, acetals $\mathbf{3}$, and rearranged compounds $\mathbf{4}$, have been synthesized and their inhibitory potential to prevent mast cell degranulation as well as $\mathrm{LTB}_{4}$ production was evaluated. Significant inhibition of mast cell degranulation induced by the activation of Fce receptor type I showed certain derivatives with alkyl and halogen substituents as well as combinations of those substituents, whereas unsubstituted compounds and those with hydroxy and methoxy substituents gave the poorest inhibitions.

Position $R_{1}$ is tolerated for Me substituent like in $\mathbf{2 i}$ and 3r. Majority of the active compounds are unsubstituted on position $\mathrm{R}_{2}$, however, some compounds with $\mathrm{R}_{2}=\mathrm{iPr}$ or $\mathrm{Cl}$ shown inhibition larger than $50 \%(\mathbf{2 d}, \mathbf{2 0}, \mathbf{4 0}, \mathbf{3 l}, \mathbf{4 I})$. On the other hand, compounds with oxygen in $\mathrm{R}_{2}\left(\mathrm{R}_{2}=\mathrm{OH}\right.$ and $\left.\mathrm{OMe}\right)$ haven't shown any activity. Compounds $2 \mathrm{e}$ and $4 \mathrm{e}$ where $\mathrm{R}_{3}=\mathrm{Cl}$ shown inhibitor activity larger than $75 \%$. Position $R_{4}$ is tolerated for larger lipophilic substituents like Et (2n, 3n, 4n) and $i \operatorname{Pr}(\mathbf{2 p}, \mathbf{4 p})$. Additionally, in combination with $\mathrm{R}_{2}=\mathrm{Me}$, compounds where $\mathrm{R}_{4}=\mathrm{Cl}(3 \mathbf{r})$ and $\mathrm{Me}$ $(\mathbf{2} \mathbf{i}, 3 \mathbf{i}, \mathbf{4 i})$ shown the best activities in this set.

Significant inhibition of $\mathrm{LTB}_{4}$ exhibited monoand bi-alkyl substituted compounds $\mathbf{2 h}-\mathbf{j}, \mathbf{2 m - p}, \mathbf{3 o}-\mathbf{p}$, and $\mathbf{4 o -}-\mathbf{p}$ as well as 5-methyl-8-chloro substituted derivative $\mathbf{3 r}$.

Selected compounds, $\mathbf{3 p}, \mathbf{4 p}$ and $\mathbf{3 r}$, exhibited significant anti-inflammatory activity in PMA induced ear edema in CD1 mice, with potency equal (compounds 3p and $4 p$ ) or better (compound 3r) in comparison with zileuton as the reference compound. This is very significant finding since it opens a new possibility of developing new class of non-steroidal compounds for the treatment of inflammatory diseases.

Further structural modifications are in progress with a view to shedding light on the better understand- ing of anti-inflammatory activity of 4-hydroxycoumarin compounds and critical structural parameters that affect biological activity.

\section{Abbreviations}

RBL-2H3 - Cell line of rat basophilic leukaemia

$\mathrm{LTB}_{4}$ - Leukotriene $\mathrm{B}_{4}$

IgE - Immunoglobulin E

Fce receptors $-\mathrm{Fc}$ receptors that bind $\mathrm{IgE}$

PMA - Phorbol 12-myristate 13-acetate

DMEM - Dulbecco's modification of Eagle's medium

FBS - Fetal bovine serum

ELISA - Enzyme-linked immunosorbent assay

ANOVA - Analysis-of-variance statistical test

Supplementary Materials. - Supporting informations to the paper are enclosed to the electronic version of the article. These data can be found on the website of Croatica Chemica Acta (http://public.carnet.hr/ccacaa).

Acknowledgements. The authors are thankful to Dr. Vesna Eraković Haber for helpful discussions and Biserka Ragač and Željko Osman for their outstanding technical assistance.

\section{REFERENCES}

1. I. Weinmann, Hystory of the Development of Coumarin and Coumarin-related Compounds, in: R. O'Kennedy and R. D. Thornes (Eds.), Coumarins Biology, Applications and Mode of Action, John Wiley \& Sons, Chichester, 1997, pp. 1-22.

2. M. A. Stahmann, C. F. Huebner, and K. P. Link, J. Biol. Chem. 138 (1941) 513-527.

3. H. A. Campbell, M. A. Stahmann, C. F. Huebner, and K. P. Link, U.S. Patent 2,601,204 19520617 CAN 46:50059 (1952).

4. K. Fučik, Z. Prochazka, and J. Štrof, Collection Czehoslov. Chem. Communs. 16 (1951) 304-318.

5. K. Fučik, Z. Prochazka, and J. Štrof, Collection Czechoslov. Chem. Communs. 16 (1951) 296-303.

6. M. A. Hermodson, W. M. Barker, and K. P. Link, J. Med. Chem. 14 (1971) 167-169.

7. M. Ikawa, M. A Stahmann, K. P Link, J. Am. Chem. Soc. 66 (1944), 902-906.

8. W. R. Sullivan, C. F. Huebner, M. A. Stahmann, and K. P. Link, J. Am. Chem. Soc. 65 (1943) 2288-2291.

9. D. Cooke, B. Fitzpatrick, R O'Kenedy, T. McCormack, and D. Egan, Coumarins-Multifaceted Molecules with Many Analytical and Other Applications, in: R. O'Kenedy and R. D. Thornes (Eds.), Coumarins Biology, Applications and Mode of Action, John Wiley \& Sons, Chichester, 1997, 303-336.

10. L. Wu, X. Wang, W. Xu, F. Farzaneh, and R. Xu, Curr. Med. Chem. 16 (2009) 4236-4260.

11. H. Zhao, N. Neamati, H. Hong, A. Mazumder, S. Wang, S. Sunder, G. W. A. Milne, Y. Pommier, and T. R. Burke (Jr.), J. Med. Chem. 40 (1997) 242-249.

12. H. Zhao, N. Neamati, Y. Pommier, and T. R. Burke (Jr.), Heterocycles 45 (1997) 2277-2282.

13. A. Mazumder, S. Wang, N Naemati, M. Nicklaus, S. Sunder, J. Chen, G. W. A. Milne, W. G. Rice, T. R. Burke (Jr.), and Y. Pommier, J. Med. Chem. 39 (1996) 2472-2481.

14. A. D. Patil, R. P. Ilertzberg, G. B. Dreyer, A. J. Freyer, J. W. Westley, B. Chenera, and M. L. West, PCT Int. Appl. WO 9414789 A1 19940707 CAN 121:170524 (1994). 
15. M. Orita, S. Yamamoto, N. Katayama, M. Aoki, K. Takayama, Y. Yamagiwa, N. Seki, H. Suzuki, H. Kurihara, H. Sakashita, M. Takeuchi, S. Fujuta, T. Yamada, and A. Tanaka, J. Med. Chem. 44 (2001) 540-547.

16. S. Y. Ryu, N. Y. Kou, H. S. Choi, H. Ryu, T. S. Kim, and K. M. Kim, Planta Med. 67 (2001) 172-174.

17. S. Kishiro, S. Nunomura, H. Nagai, T. Akihisa, and C. Ra, Biol. Pharm. Bull. 31 (2008) 442-448.

18. J. Nakano, T. Awaji, K. Kuriyama, Y. Hiyama, and T. Okuda, Eur. Pat. Appl. EP 184801 A1 19860618 CAN 105:97482 (1986).

19. D. R. Buckle, B. C. C. Cantello, and H. Smith, Brit. Pat. GB 1454247 A 19761103 CAN 86:155514 (1976).

20. D. R. Buckle and H. Smith, U.S. Patent 4,200,577 A 19800429 CAN 93:186172 (1980).

21. D. R. Buckle, B. C. C. Cantello, H. Smith, and B. A. Spicer, J. Med. Chem. 18 (1975) 391-394.

22. M. Ghate, R. A. Kusanur, and M. V. Kulkarni, Eur. J. Med. Chem. 40 (2005) 882-887.

23. S. Stanchev, V. Hadjimitova, T. Traykov, T. Boyanov, and I. Manolov, Eur. J. Med. Chem. 44 (2009) 3077-3082.

24. I. Kostova, Mini-Rev. Med. Chem. 6 (2006) 365-374.

25. K. C. Fylaktakidou, D. J. Hadipavlou-Litina, K. E. Litinas, and D. N. Nicolaides, Curr. Pharm. Des. 10 (2004) 3813-3833.

26. F. Epifano, M. Curini, L. Menghini, and S. Genovese, Mini-Rev. Med. Chem. 9 (2009) 1262-1271.

27. M. A. Musa, J. S. Cooperwood, and M. A. F. Khan, Curr. Med. Chem. 15 (2008) 2664-2679.

28. L. Santana, E. Uriarte, F. Roleira, N. Milhazes, and F. Borgesc, Curr. Med. Chem. 11 (2004) 3239-3261.

29. M. Darbarwar and V. Sundaramurthy, Synthesis (1982) 337-388.

30. 30. S. D. Demo, E. Masuda, A. B. Rossi, B. T. Throndset, A. L. Gerard, E. H. Chan, R. J. Armstrong, B. P. Fox, J. B. Lorens, D. G. Payan, R. H. Scheller, and J. M. Fisher, Cytometry 36 (1999) 340-348.

31. E. J. Barreiro, Curr. Med. Chem. - Anti-Inflamm. and AntiAllergy Agents 3 (2004) 9-18.

32. M. Balazy, Current Drug Targets - Inflammation and Allergy 3 (2004) 19-33.

33. M. Gabor, J. Toxicol. 21 (2002) 191-202.

34. L. Lerman, A. Čempuh Klonkay, A. Filipović Sučić, and I. Elenkov, Eur. J. Mass Spectrom. 10 (2004) 523-539.

35. Z. Otwinowski, W. Minor, Methods in Enzymology, Vol. 276, Macromolecular Crystallography, Part A, edited by C.W. Carter, Jr., \& R.M. Sweet, New York:Academic Press, 1997, 307-326.

36. G. M. Sheldrick, SHELXS97 and SHELXL97. Program for crystal structure solution and refinement University of Göttingen, Germany, 1997.
37. A. D. Becke, J. Chem. Phys. 98 (1993) 5648-5652.

38. P. J. Stephens, F. J. Devlin, C. F. Chabalowski, and M. J. Frisch, J. Chem. Phys. 98 (1994) 11623-11627.

39. A. P. Scott and L. Radom, J. Phys. Chem. 100 (1996) 16502-16513.

40. Jaguar, version 7.8, Schrödinger, LLC, New York, NY, 2011.

41. Maestro, version 9.2, Schrödinger, LLC, New York, NY, 2011.

42. S. M. Desai, R. R. Shah, and K. N. Trivedi, Chemistry and Industry (1983) 827-828.

43. a) H. Nakata, A. Tatematsu, H. Yoshizumi, and S. Naga, J. Chem. Soc. Perkin. 1 (1972) 1924-1928; b) W. R. Porter and W. F. Trager, J. Heterocyclic Chem. 19 (1982) 475-480; c) B. Talapatra, S. K. Mandal, K. Biswas, R. Chakrabarti, and S. K. Talapatra, J. Indian. Chem. Soc. 78 (2001) 765-771.

44. a) E. J. Valente, W. R. Porter, and W.F. Trager, J. Med. Chem. 21 (1978) 231-234; b) E. J. Valente, B. D. Santarsiero, and V. Schomaker, J. Org. Chem. 44 (1979) 798-802.

45. a) M. Merćep, M. Mesić, B. Hrvačić, I. J. Elenkov, I. Malnar, S. Marković, L. Šimičić, A. Čempuh Klonkay, and A. Filipović, PCT Int. Appl. WO 2005010006 A1 20050203 CAN 142:198049 (2005); b) M. Merćep, M. Mesić, B. Hrvačić, I. J. Elenkov, I. Malnar, S. Marković, L. Šimičić, A. Čempuh Klonkay, and A. Filipović, PCT Int. Appl. WO 2005010007 A1 20050203 CAN 142:176821 (2005); c) M. Merćep, I. Malnar, B. Hrvačić, S. Marković, A. Filipović Sučić, R. Rupčić, A. Hutinec, I. J. Elenkov, M. Mesić, B. Bošnjak, and A. Čempuh Klonkay, PCT Int. Appl. WO 2006111858 A2 20061026 CAN 145:454935 (2006).

46. C. E. Brightling, P. Bradding, I. D. Pavord, and A. J. Wardlaw, Clin. Exp. Allergy 33 (2003) 550-556.

47. M. K. Church, J. P. Caulfield, Mast Cell and Basophil Functions; in: S. T. Holgate and M. K. Church (Eds.), Allergy, MosbyWolfe, London, 1995, 5.1-5.12.

48. S. Dragojević, V. Šunjić, V. Bencetić-Mihaljević, J. Ralić, M. Mesić, I. J. Elenkov, A. Filipović-Sučić, A. Čempuh Klonkay, L. Lerman, M. Ilijaš, V. Gabelica-Marković, and I. Malnar, J. Pharm. Biomed. Analysis 54 (2011) 37-47.

49. M. Napoletano, E. Moriggi, A. Mereu, F. Ornaghi, G. Morazzoni, R. Longoni, C. Riva, L. Pacchetti, and F. Pellacini, PCT Int. Appl. WO2004013153 A2 (2004).

50. J. M. Young, L. M. De Young. Cutaneous models of inflammation for the evaluation of topical and systemic pharmacological agents; in: J. Y. Chang and A. J. Lewis (Eds.), Pharmacological methods in the control of inflammation, Alan R. Liss, Inc., New York, 1989, pp. 215-231.

51. C. Romay, N. Ledón, and R González, Arzneimittel-Forschung 50 (2000) 1106-1109. 